\title{
Our Entire Future and the Past Are Actually Stories We Tell Ourselves and Others
}

\author{
Fulya Kincal
}

\begin{abstract}
Being human inevitably means attaching meaning to essentially meaningless universe. Storytelling is the simplest way of attaching meaning and what differentiates human beings from other inhabitants of the world. In this context, our reality is determined by the stories. Like every work of literature, life of human beings is an intertext where different texts, styles and themes interact in a story-like order. In their novels Don Quixote and Never Let Me Go both Cervantes and Kazuoro Ishiguro are showing that stories can generalize and extract the truth by penetrating to the hearth of human condition. As such, these stories mature man's knowledge about himself and the world. Both writers assert that as times passes we experience different stories and our world is continuously altered by the new stories. Through stories we internalize our environment, our past and present. From this perspective, this paper aims to demonstrate our own position regarding to stories in life and common features of human beings referring to the tradition of storytelling.
\end{abstract}

Index Terms-Meaning, story, storytelling, understanding, reality.

\section{INTRODUCTION}

Story-making instinct is a distinctive feature of human beings. While communication and language are also belonging to animals, narration is unique to human beings, and has been vital to the growth of human civilization for centuries. It is a way of attaching meaning to the things and a construction of meaning to understand events. Two novels, Miguel Cervantes's Don Quixote and Kazuoro Ishiguro's Never Let Me Go, indicate how we live in and live by stories and how the stories in fiction represent our engagements with stories in real life. The novels focus on the fact that we are fascinated and dependent on stories, and through the experience of making, reading or listening to stories we expand our character and our web of experiences, improve our understanding of the world and answer mysterious conditions of life [1]. The complex nature of reality, with its contradiction is represented by characters' obsession with stories and their effort to reach the meaning of life out of that obsession. We can easily recognize how interrupted stories being told by characters led to the revelation of other stories not being told or being told obliquely. In all of the cases resulted from various stories, memory is the key element. Like storytelling, memory is a human quality and we narrate

Manuscript received December 9, 2013; revised January 15, 2014. This study was prepared by being used as the $\mathrm{PhD}$ paper of the author in the $1 \mathrm{st}$ place made in Ege University.

Fulya Kincal is with the Department of English Language and Literature in 2012 and the School of Foreign Languages, University of Kirklareli, Kırklareli, 39100, Turkey (e-mail: fulya. kincal@ kirklareli.edu.tr). in terms of our memories. The interplay of memory and narrative is the overall network of interrelated and intertwined stories that take place and told in the Sierra Morena and Hailsham. While Don Quixote makes up his generic chivalric novel drawing from his recollections of the chivalric romances that he has read in the past, Ishiguro demonstrates how storytelling shapes memories through story skeletons in Never Let Me Go.

If life is a mass of adventure which is resulted from human need for change, excitement and freedom in an open-ended, indeterminate world, all these adventures gain liveliness through stories. Stories are the accounts of activities that have taken place and carry importance and that is to be contemplated. A story never ends; it just connects to the next event. Even when we die, our life is distilled in to significant events and actions that are recounted through the story which keeps the truth and essence of our life. Thus the past connects itself with the future [2]. In Cervantes' novel, Quixote is obsessed with stories and he threatens the boundary between fantasy and reality when he charges off in imitation of his fictional hero Amadis to right all manner of wrongs and win eternal renowned and everlasting fame. Quixote remains sure that some future author will chronicle his great deeds, and that signifies his awareness of his own role in the story he creates for himself as he makes his world a better place [3]. While Don Quixote parodies chivalry romances and renaissance ideology concerning human vices and virtues, it essentially engages itself with the view that everything is a model or an image which is based on the real stories of past. $\mathrm{He}$ believes that these stories, present and even future are intricately interwoven. Quixote insists on living through an authentic chivalrous soul because he is subversively aware that what is normally taken as a solid and real world is actually just the construction of some earlier stories. He declares that by denying and suppressing this past, people would deny who they are.

Another significant point regarding the great importance of stories is witnessed in Kazuoro Ishiguro's novel Never Let $M e$ Go. Everything the students of Hailsham do is based on rumors; they continuously follow these rumors throughout the novel. Creating stories about the facts of their limited life, they try to give meaning to their past, present and future. They try to form a connection between their imaginations and experiences. Narration and memorization are unique to human beings but the cloned bodies of Hailsham also tell stories. From this perspective Kazuoro Ishiguro's novel questions how we can separate these man-made clones from God-made man. These examples of one character or characters' fascination with stories represent our collective fascination with and dependence on stories. The use of 
stories is clearly related to the fact that the world does not come to us with meaning but we attach meaning to life throughout them. Every story is a way of explaining something to us.

\section{DON QuiXOTE}

As in our lives, in the novels we find ourselves in the individual stories which talk to one another and come together to suggest a larger story, but are intended, as well, to stand alone. Cervantes is aware of how stories activate the mind at the same time that they harmonize experience. In Part I of Don Quixote especially, Cervantes pointedly uses small narratives to elaborate on themes and improve the effect of smaller stories. They give meaning to Quixote's disorganized world of adventure. Two inserted stories in particular harmonize the novel's disparate events, as well as dramatize two significant themes and ideas that Quixote delivers in unusually eloquent discourse. Don Fernando's story of false love, true love, betrayal, and anguish includes four characters: himself, Luscinda, Dorotea, and Cardenio, and winds through chapters 23 to 36 of Don Quixote Part I. In the novel, the character Cardenio meets and tells his story to Don Quixote and Sancho while he was wandering in the mountains of Sierra Morena. Cardenio is a good-natured son of a wealthy family and falls in love with Luscinda, daughter of another wealthy and noble family at a young age. They grow up together and exchange letters. Cardenio even writes verses to Luscinda. Cardenio determines to have his own father ask permission for Luscinda's hand in marriage after he asks Luscinda's father for permission. But when he approaches his father, he is given a letter from the Duke Ricardo, asking for his immediate services as a companion to his son, promising Cardenio a higher rank for his troubles. Cardenio gives farewell to Luscinda, and requests that her father wait until Cardenio has settled his summons with the Duke. Cardenio is well received at the court and the Duke's son, Don Fernando who readily accepts his companion. During a visit Don Fernando sees Luscinda, and finds one of Cardenio's verses to Luscinda and falls madly in love with her. In Cardenio's timidity of asking his father to ask for Luscinda's hand, Don Fernando offers to ask Cardenio's father for him. Cardenio returns to the Duke's court to request an end to his employment, and the Duke's son requests Cardenio stay for a week until his father's arrival. Cardenio stays as unaware of the plans of Don Fernando who desires Luscinda for himself. During the wait, Cardenio receives a letter from Luscinda telling him that Don Fernando has taken her by force with plans of marriage. Cardenio rushes to Luscinda's house, and in secret she tells him that while the marriage is about to occur, she has hidden a dagger and plans to impale herself before saying her vows. However, at the marriage ceremony Luscinda does not do what she promises. Here, madness takes Cardenio and he leaves for the Sierra Morena, and the novel continues in the present. In the next part of the story, Cardenio encounters Dorotea, a woman dressed up as a man. When he asks Dorotea if she is in some sort of trouble, she tells her story. Dorotea is the daughter of a farmer who has been hired to do work for a wealthier man. This manager's son becomes fond of Dorotea and ultimately coerced her into having a relationship with him. The man promises to marry Dorotea but in fact, he was already married and after he seduces Dorotea, he abondens Dorotea and returns her wife. This becomes the traumatic event of Dorotea's life. As it turns out, it becomes clear that Don Fernando who deceives Cardenio and steals Luscinda is the man who has deceived Dorotea. When Cardenio and Dorotea compare stories, Cardenio learns that Lucinda continued to love him even when she was forced to marry Don Fernando. All these stories that take place or are told in Sierra Morena are resolved at Juan Palomeque's inn. Two of this story's four players relate the story to different audiences at different times. "The reader completes the entire story piecemeal, as in the way he or she assembles the world at large from the disconnected events he or she perceives. Fernando's deception of the trusting Dorotea, and Cardenio's incurable anger at Luscinda's betrayal of him to marry Don Fernando, contrast the theme of the Golden Age which Quixote delivers in chapter 11[4]." Quixote describes noble morals and values create an Eden-like world through these sentences:

"... During that epoch the world was filled with peace, friendship and concord, as yet the dull share of the crooked plough had not dared to rend and pierce the tender bowels of our first mother that without compulsion yielded from every portion of her broad fertile bosom all that could satisfy, sustain, and delight the children that then possessed her. Then was it that the innocent and fair young shepherdess roamed from vale to vale and hill to hill, with flowing locks, and no more garments than were needful modestly to cover what modesty seeks and ever sought to hide. Nor were their ornaments like those in use to-day, set off by Tyrian purple, and silk in endless fashions, but the wreathed leaves of the green dock and ivy, wherewith they went as bravely and becomingly decked as our Court dames with all the rare and far-fetched artifices that idle curiosity has taught them. Then the love-thoughts of the heart clothed themselves simply and naturally as the heart conceived them, nor sought to commend themselves by forced and rambling verbiage. Fraud, deceit, or malice had then not yet mingled with truth and sincerity. Justice held her ground, undisturbed and unassailed by the efforts of favour and of interest that now so much impair, pervert, and beset her. Arbitrary law had not yet established itself in the mind of the judge, for then there was no cause to judge and no one to be judged. Maidens and modesty, as I have said, wandered at will alone and unattended, without fear of insult from lawlessness or libertine assault, and if they were undone it was of their own will and pleasure. But now in this hateful age of ours not one is safe, not though some new labyrinth like that of Crete conceal and surround her; even there the pestilence of gallantry will make its way to them through chinks or on the air by the zeal of its accursed importunity, and, despite of all seclusion, lead them to ruin. In defense of these, as time advanced and wickedness increased, the order of knights-errant was instituted, to defend maidens, to protect widows and to succour the orphans and the needy [5]".

Cardenio's misery as he lives in the Sierra Moreno is described in chapters 23,24 , and 37 . It is the most vivid example of this contrast. Luscinda's unhappiness as she 
relates it in chapter 36 equally impresses the reader, as does Dorotea's swoon when she hears Cardenio and sees Don Fernando, also described in chapter 36. [4] Cervantes consciously takes his protagonist away from the center of the different but related stories involving four characters while still engaging him in the unfolding and resolution of the inserted tales at Juan Palomeque's inn. In the same way, the much-studied Captive's Tale dramatizes and challenges Quixote's speech in chapters 37 and 38 of Part I. Quixote is insistent on the superiority of knights over scholars and learning. The tale narrates episodes of Battle of Lepanta to corroborate Don Quixote's ideas on the issue of the superiority of arms and military glory over letters. According to the tale a captive has chosen to pursue a career in serving in the king's army rather than the church, the sea. Having fought in a number of wars that took him to Genoa, Milan, Flanders, Algiers, Malta, and Constantinople, the captive is imprisoned and then frees and kidnaps a beautiful Moorish noblewoman named Lela Zoraida. Before the captive tells his story, Don Quixote gives a speech praising the glories of knighthood:

"Now, there can be no doubt that this art and calling surpasses all those that mankind has invented, and is the more deserving of being held in honor in proportion as it is the more exposed to peril. Away with those who assert that letters have the preeminence over arms; I will tell them, whosoever they may be, that they know not what they say. For the reason which such persons commonly assign, and upon which they chiefly rest, is, that the labors of the mind are greater than those of the body, and that arms give employment to the body alone; as if the calling were a porter's trade, for which nothing more is required than sturdy strength; or as if, in what we who profess them call arms, there were not included acts of vigor for the execution of which high intelligence is requisite; or as if the soul of the warrior, when he has an army, or the defense of a city under his care, did not exert itself as much by mind as by body [5]".

According to Don Quixote arms are superior to letters but the contrary position of letters' superiority over arms emerges when a judge, a man of letters and the Captive's brother resolves the Captive's and Zoraida's situation in chapter 42. The captive's story entails both an unequal marriage, that is, social inequality and a marriage that crosses racial and religious boundaries because it's a union through love between a Moor and a Muslim, and a Spaniard and a Christian. The social and religious clash is resolved when Zoraida is converted into Christianity and all impediments for them to marry were removed by a man of letters, a judge. Using these and other stories within the larger story of his novel, Cervantes harmonizes the seemingly disconnected and chaotic events that his crazy Quixote encounters throughout Part I [3]. these events seem disorganized and mixed up and indicate Quixote's mentality as he embodies knight errantry. But by using stories within stories, Cervantes harmonizes these disparate events by the end of his novel, transforming his crazy Don Quixote into the ingenious knight from La Mancha, as Sancho Panza frequently calls Quixote. Through different stories which provide various perspectives and experiences, Quixote improves understanding of his world; even changes his mind on certain issues. Thus Cervantes' novel about this crazy and ingenious knight becomes a microcosm of our storytelling tradition that is essential to both our own self-improvement and our civilization's development. What the Quixote, as a book, shows us is how we are either consciously or unconsciously affected by stories that surround our lives.

In addition to Cervantes' inserted stories, his layered narrative structure makes Don Quixote a microcosm of our society's storytelling tradition. "The reader reads about Don Quixote of La Mancha from four distinct narrators: Cide Hamete Benengeli, plus the translator of Benengeli's Arabic manuscript, plus the so-called Second Author (who is identified with Cervantes himself by many), and finally the original author. Although reader recognizes only one obvious narrator, existence of a variety of other narratives is interspersed throughout the novel [4]." John Allen finds that "this whole complex structure of the novel leads the reader to increased identification with the protagonist, rather than with any of the shifting storytellers [1]." This seems to be exactly Cervantes' purpose in writing Don Quixote: to demonstrate our amusing madness at such a balance within and dependence on the web of stories comprising our lives and our world. These patterns of stories within stories, and storytellers within storytellers, show to what deep extent Cervantes is aware of the importance of stories for his real world readers. He knows readers want to lose themselves into the complexity of stories, since life as a collection of multiple stories offers more than that. Thus he writes the larger story of Don Quixote out of his central character's obsession with stories of knight errantry. Clearly, stories were one of Cervantes' own fascinations, too. So the Quixote is a book about how to read, how to interpret stories, and in life how we are surrounded by stories of all kinds, not just in literature.

\section{NEVER LET ME Go}

In Never Let Me Go, a kind of story-making turns around and the overwhelming majority of these stories are related to "the Gallery" and "the Madame". They are the most distinguishing mysteries which require response in terms of the life of the students. In the first part of the novel, students are encouraged to create artwork such as paintings and poetry instead of science and math normal for school children, and their best work gets into "The Gallery". They know the existence of The Gallery, the excitement and the pride it gives when their works are praised in terms of it, since "it was a great honor to have something taken by Madame collided with a feeling that they were losing our most marketable stuff [6]." But actually none of them is sure what it is completely. In the same way, all the students are used to the regular visits of the Madame, they know her slim fit appearance well, but they do not acknowledge her relation with the works they do. So each student tries to make up a story to make sense of these issues. The author draws his reader's attention to the human being's instinct of story-making and story-telling. He emphasizes the eternal attempt of creating stories as responses to the unanswerable or unknown conditions of life. As mythologist Joseph Campbell said they live by stories and they live in stories. Through these stories, they strive to form a collective consciousness and become more civilized as 
cultural beings.

The tradition of storytelling is especially emphasized by Ishiguro through his narrative's centering on memories. The memories of Kathy, Ruth, Tommy and Hailsham exist in all parts of Never Let Me Go. The author gives importance to the memory stressing on how we narrate in terms of our memories. Memory, memory of the past, is the major issue of the novel because all the characters especially Kathy, the protagonist, would probably get lost if she does not remember. Looking at the continual shifts from present to past and from past to present, it is easy to see the life of Kathy falling into two distinct mental activities; forgetting and remembering. Hailsham is a stuff of remembrance so Kathy, Tommy, Ruth and others remember themselves throughout the memory of Hailsham. Everything which is away from the Hailsham is darkness.

Subversive theme in the story of Never Let Me Go is the process of mythmaking. Myths are common stories about the human existence, behavior, or history. In these stories we firstly talk about creation because we are always interested in how we are created as soon as we become self-conscious creatures. Thus, all mythology begins with a creation story and mythology has to exist because of that unknown origin. In the novel, origins of the Hailsham students are in the dark so they create stories to give an answer to the questions about coming into being. As in the novel, in the real life we have collective stories which are responses to unanswerable stories and questions. Even if the world is dominated with such stories, there always exist a lot of questions to be explained.

"The Gallery" is the most disturbing mystery of the novel. Everything begins when students try to explain the mystery related to "the gallery". Every part of the Hailsham culture is designed around a complicated network of myths that have developed over the symbolic order in which the symbols like "the gallery", "the Madame" carry messages about the question of their life. It would be an extraordinarily rare event for these children as much as all children to grow up without collecting a set of mythical beliefs which they will accept throughout his or her lifetime as eternal truths because these symbols and beliefs say who we are or they are.

To translate the complexities of social reality into story form, Schank and Abelson argue that story construction usually involves stretching evidence to conform to the contours of a relatively simple skeleton theme. "This means, in effect, that one has to lie. We must leave out the details that don't fit, and invent some that make things work better [7]." As a result of this process, the "laundered version" of events is largely what is remembered. "We lose the original and keep the copy [7]." Kathy exemplifies this cognitive period of her mind in these statements in the novel:

"In my memory my life at Hailsham falls into two distinct chunks: this last era, and everything that came before. The earlier years-the ones I've just been telling you about-they tend to blur into each other as a kind of golden time, and when I think about them at all, even the not-so-great things, I can't help feeling a sort of glow. But those last years feel different. They weren't unhappy exactly-I've got plenty of memories I treasure from them-but they were more serious, and in some ways darker. Maybe I've exaggerated it in my mind, but I've got an impression of things changing rapidly around then, like day moving into night [6]".

Furthermore, Schank and Abelson contend that, over time, details fade and only the story skeleton remains [7]. In this sense, story skeletons become central to the storytelling process. Coherent stories are built around skeleton representations and are subsequently used to simplify thinking and communicating about social episodes. As well as helping to organize the stories, however, Schank and Abelson contend that over time skeletons act as schemata that guide selective and reconstructive memory [7]. Over time, people remember and reconstruct only information that corroborates the story skeleton, which ultimately strengthens it. In other words, Schank and Abelson propose that story skeletons act like "glue" for story-consistent information, making it more accessible than information that does not flesh out the story line [7]. According to this perspective, story skeletons influence memory at retrieval. In the novel, Kath's memories are based on the two important stories of the novel and through these stories she can share her story with the reader. The stories of "deferral" and "the gallery" are the particular details through which all Hailsham students construct story skeletons of them. From this perspective, Kathy denotes the importance of memory in her life with her statements of:

"Memory is quite central for me. Part of it is that I like the actual texture of writing through memory. Memories, even your most precious ones, fade surprisingly quickly. But I don't go along with that. The memories I value most, I do not ever see them fading [6]".

For Kathy memory is not just a repository of recollections and stories from the past, it is that which structures the self in the present and the archive where we narrate issues as the reflection of what happened in relation to the present moment. Furthermore, her story is the revelation of a truth about her state as she talks now. So it is a truth about now, about the present and about the past.

To indicate the importance of stories for a culture, Martha Nandorfy conveys Thomas King's claim that "the truth about stories is that that's all we are [8]." Nandorfy goes on to say, "King's statement doesn't mean that we are paltry creatures, but that stories encompass everything; that our reality is determined by which stories we choose to remember or create, and which stories we live by. Stories are not representations; a story is not just a story but has the power to conjure reality into being [8]." Clearly, stories are essential to our world. Guillermo Corona, writing about Don Quixote, makes a similar claim to Nandorfy's: "the complex nature of reality, with its contradictions, has its parallelism in a strucsasture of stories in which there are also contradictions [8]." We see this in Don Quixote, when the complex nature of Quixote's reality resolves into the interpolated novels, in Never Let Me Go when the reality of the student's life resolves through the novel. With Quixote and Ruth and others, we see that what is true about literature in general is also true to real life: like every work of literature, life of human being is an intertext where different texts, styles and themes interact in a story like 
order. Both Quixote himself and the students of Hailsham are so full of stories, texts, and intertexts, that their great amalgamation alters continuously their reality. Similarly, we see our world altered by the stories - both factual and imaginative - that weave the web of reality each one of us lives by.

According to modern research and story theory, Quixote's and the Hailsham students' transformative obsession with stories become more realistic and important when as reader we see them as a reflection of our own self in an attempt of balancing the web of stories that comprises our world. Otherwise it does not become possible to bring meaning to our life. Quixote's concern for his future history, in Never Let Me Go Chrissie and Rodney's hope related to deferral represent each of our concerns with our own lives, future and what we have left behind. Quixote's admiration for Amadis represents our admiration for cultural and personal heroes. Quixote's experience of disconnected events represents our own daily lives, unified only by our single apprehension of these events. Ruth's hope of being the clone of a respectable person and all the imaginations related to this hope refer to the desire of belonging to a higher part of the society. Even if they are copies, they emphasize being the copies of respectable citizens of the society. All the imaginations and the stories they formed in terms of their past and their future refer to the process of internalization which is the common endeavor of all human beings. The imaginations mingle with reality and they also fertilize reality. That's why through the stories we internalize our environment, our past and our present.

\section{The Best Storytellers OF Two Novels}

Especially two characters, Ruth of Ishiguro and Quixote of Cervantes become significant symbols for the storytelling tradition in the novels. They both reflect some common features of human beings regarding to the tradition of storytelling and story-making. According to Walter Benjamin, there are two types of storytellers; those who travel around the world and have life experiences, those who stay within the historical fabric of their own hometown [2]. Quixote belongs to the first category and seems as one of the best storytellers like artisans because he both travels for a while and then returns to lay down roots in his community. He engages in two kinds of journies; after he responds to a variety of stories in an imaginary world, he returns to reality not as the same Quixote. Most authors find it ironic that "from the debut of Cardenio in chapter 23 until Quixote's return home in chapter 46 , the madcap knight's role in events is largely peripheral", particularly regarding the two major subplots of Don Fernando and the Captive. Cervantes takes his protagonist away from the center of the story while still engaging him in the unfolding and resolution of the intercalated tales involving Cardenio, Fernando, Dorotea and Luscinda. Quixote's position is our position regarding many stories we encounter, since we sit as spectators to past history, to court cases shaping our laws and our civilization, to news reports flashing our daily realities across a screen [1]. Even if we do not always participate the world and reality that surround us, these realities nonetheless give shape to our emotions and judgments. They give shape to the descriptions of events and actors, facts and situations, true and imagined, so that we are compelled to change in the way the history taking shape around us. He seems not as important or interested in as other people in these particular narratives. He removes from the reality taking shape around him as he sits focused on stories of knight errantry, takes every opportunity to enact the virtues of knight errantry. But regarding the major interpolated stories within his novel, Quixote changes his impressions and improves his sense of understanding because stories and storytelling contains the key ingredient for the formation of experience and wisdom. Stories are the most affective way of handing down experience through ages.

In his essay "The Storyteller" Walter Benjamin asserts that the best storytellers are those who account the stories in such a way which gives the audience the opportunity to connect with the story and reflect on their own interpretation of the deeds [2]. Ruth seems as the master story-teller in the novel because her story offers her audience the opportunity to connect and reflect on the significance and the meaning of the story in different terms. Every person can uniquely exaggerate the myth of the story and even fabricate a larger truth.

Whenever someone talks about anything which is mysterious, "Ruth comes up with another theory [6]." As in the example of Madame who is thought as "snooty" due to the fact that she does not talk to them and keep the students at a distance with her chilly look, it is Ruth who writes the story about Madame's fear related to the students. In addition to Madame's reactive feelings, the story of "deferral" is also her creation [6]. That's why she is taken by Chrissie and Rodney to Nortfolk, since they hope to hear the whole story about the "deferral". The author again draws his reader's intention to the common feature of all human beings. Although both communication and language belong to the animals like human beings, the story-telling and story-making instinct creates a distinctive feature which is unique to people. It separates us from the rest on earth. As 'clones', Hailsham students talk about creation just as our first stories that always try to answer these questions about coming into being. As soon as we became self conscious creatures, we are all interested in stories and try to reach the answer of creation. As a result, we have collective stories which give the opportunity of making sense of our past, present and future such as myths and religious stories.

\section{CONCLUSION}

Both novels are incredibly well-unified works, in which the interpolated stories of Don Quixote and childish imaginary stories of Never Let Me Go are as much a part of structure as the deeds of main characters. Despite the seeming chaos of Don Quixote with its haphazard, random adventures, its confusions and untidy state of minds, and its headstrong central character, the novel would not have been a representative of real life without the stories. In the novel every story in the memory of a teller reveals other stories behind the one which is told. In this context the whole network of stories turns into experiences, penetrates to the 
mind of Quixote and transforms him. The relationship of all of these stories to the main story of Don Quixote and Sancho is the universal condition of human being regarding to all stories of life. In the same way, despite the everlasting shifts from past to present, present to past and lack of information which bothers the reader until the end, the stories of Never Let Me Go give immediacy and impact and leave us thinking about its characters long after we have finished reading it. It is these stories that make our minds fizz throughout the novel and continue to fizz when we have left the novel behind us. It is these stories which transform fictional characters into real characters and real life into fiction.

Four hundred years after its conception, Don Quixote continued inspiring artists and thinkers. It is still acknowledged as a corner stone in literary tradition. Quixote's sublime madness of his obsession with stories is one of the crucial factors that settle the novel into the present place. This obsession parallels our own, as we, amidst the web of stories comprising our lives, strive ingeniously to harmonize our world through telling and listening to stories, true and imaginative, as we strive to create not only our personal, but also the great human history.

As a novel which has been adapted to a film, Never Let Me $G o$ is regarded as the best novel of the decade. This popularity depends on its focus on the sense of how memory and narration might be used as a tool to maintain a sense of self. In one of his interviews, Ishiguro says that there are things in Never Let Me Go he is more interested in than the clone thing, such as how they are trying to find their place in the world and make sense of their lives; to what extent they can transcend their fate. Most of the things that concern them concern us all, he says. In this sense, the school depicted in Never Let Me Go is not an attempted portrayal of a probable future, but rather a theoretical exploration of the dangerous tendencies of our age. The unbelievable world depicted through Kathy H's memories reveals itself as version of past and present human storytelling tradition. It gives its reader the feeling that all the stories circle around the novel are prophecies like the previous prophecies which came into being. How all books are products of real life and other fictional works, just in the same way our entire past is actually stories we tell ourselves and others.

\section{REFERENCES}

[1] S. J. Read and L. C. Miller, "Stories are fundamental to meaning and memory: For social creatures, could it be otherwise?" Advances in Social Cognition, vol. 8, pp. 139-152, 1995.

[2] B. Walter, The Storyteller, A Theory of the Novel Ed. Michael Mckeon, Baltimore, Maryland: John Hopkins University, 2000, pp. 361-378.

[3] J. A. John "The Narrators, the reader, and don Quixote," MLA International Bibliography, vol. 7, 2009.

[4] N. Steven. "Descartes's demon and the madness of don Quixote," Journal of the History of Ideas, vol. 58, no. 1, pp. 41-45, 2009.

[5] M. D. C. Saavedra, Don Quijote De La Mancha, Harper Collins Publishers, New York, 2003.

[6] I. Kazuo, Never Let Me Go, A Division of Random House, Inc., New York, 2005.

[7] R. C. Schank and R. P. Abelson, "Knowledge and memory: The real story," Advances in Social Cognition, vol. 8, pp. 1-86, 1995.

[8] N. Martha, "Beyond the binaries of critical thought and toward feeling-thinking stories," The Review of Education, Pedagogy, and Cultural Studies, vol. 30, pp. 316-31, 2008.

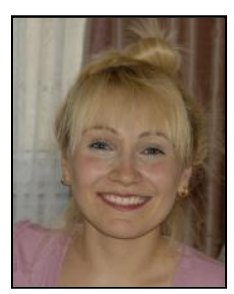

Fulya Kincal was born in Kars in 1982. She received her BA from the Department of American Language and Literature of University of Dokuz Eylül, İzmir, Turkey, in 2003. She received her MA from the Department of English Language and Literature of University of Atatürk, Erzurum, Turkey, in 2007. From 2005 to 2009, she worked as an English teacher at high schools. She similarly received her Phd from the Department of English Language and Literature of University of Ege, İzmir, Turkey.

She has published articles on fiction and drama by John Osborne, Carly Churchill

She has been working as a lecturer and the director in the School of Foreign Languages since 2008 at Kirklareli University, Turkey. Her research and teaching interests cover Victorian Novel and 20th century drama. 